\title{
KESANTUNAN BERBAHASA DALAM TINDAK TUTUR PADA BUKU CERITA ANAK ABANGKU SAYANG KARYA MARION
}

\author{
Istiqamah \\ Program Studi Bahasa Indonesia, FKIP, Universitas Muhammadiy ah Banjarmasin \\ Jalan S.Parman Komplek RS Islam Banjarmasin \\ e-mail: iscutebibeh@gmail.com
}

DOI: $10.26858 /$ retorika.v 10i2.4851

\begin{abstract}
Politeness in Speech Acts in Abangku Sayang" Story Book Written by Marion. This study aims to describe the acts of speech and politeness in a book book of my beloved by Marion. The research used pragmatic approach with descriptive method. The data is sourced from my beloved childhood story book by Marion Rayhan Az Zahra published by PT Mizan Pustaka. Data analysis is done through reading, identification, categorization, descriptions, and inferences. The results revealed five types of speech acts used, including acts of representative speech, commissive speech acts, speech acts, expressive speech acts, and declarative speech acts and six types of maxim of politeness, including maxim of wisdom, maxim of generosity, maxim of praise, maxim of humility , maxim of agreement, and maxim of sympathy.
\end{abstract}

\begin{abstract}
Abstrak: Kesantunan Berbahasa dalam Tindak Tutur pada Buku Cerita Anak Abangku Sayang Karya Marion. Penelitian ini bertujuan mendeskripsikan tindak tutur dan kesantunan dalam buku cerita anak Abangku Sayang karya Marion. Penelitian menggunakan pendekatan pragmatik dengan metode deskriptif. Data bersumber dari buku cerita anak Abangku Sayang karya Marion Rayhan Az Zahra yang diterbitkan PT Mizan Pustaka. Analisis data dilakukan melalui tahap pembacaan, pengidentifikasian, pengategorian, pendeskripsian, dan penyimpulan. Hasil penelitian mengungkap lima jenis tindak tutur yang digunakan, meliputi tindak tutur representatif, tindak tutur komisif, tindak tutur direktif, tindak tutur ekspresif, dan tindak tutur deklaratif dan enam jenis maksim kesantunan, meliputi maksim kearifan, maksim kedermawanan, maksim pujian, maksim kerendahan hati, maksim kesepakatan, dan maksim simpati.
\end{abstract}

Kata kunci: cerita anak, kesantunan berbahasa, tindak tutur

Bahasa merupakan alat utama untuk berkomunikasi dalam kehidupan manusia, baik secara individual maupun secara sosial. Salah satu aspek penggunaan bahasa dalam bentuk tulisan ialah karya sastra. Bahasa dalam sastra menjadi alat manusia untuk menyatakan perasaan, pikiran, dan angan-angannya (Alisjahbana, 1977:51). Penelitian ini penting dilakukan karena semakin berkurangnya minat membaca pada anak serta kurangnya buku bacaan anak yang berkualitas sehingga diharapkan dengan penelitian ini anak-anak menjadi tertarik dengan buku bacaan yang sesuai dengan umur mereka.

Karya sastra merupakan salah satu penyaluran pesan yang efektif untuk menyampai- kan berbagai masalah serta solusi di dalam kehidupan. Penyampaian pesan ini bisa kita sampaikan ke berbagai lapisan masyarakat, baik orang dewasa maupun anak-anak. Pesan yang disampaikan ini diharapkan memberikan dampak terhadap pembaca agar pesan yang dikandung dalam karya sastra betul-betul tersampaikan. Salah satu karya sastra yang cukup efektif dalam menyampaikan pesan-pesan dalam kehidupan adalah novel. Dalam penelitian ini, peneliti mengorientasikan kajian terhadap novel berupa buku cerita anak. Penelitian tentang kesantunan berbahasa pada buku cerita ini penting karena anak pada dasarnya adalah peniru yang baik, jadi dengan ditelitinya kesantunan berbahasa pada 
buku cerita anak ini, diharapkan anak punya teladan yang baik untuk mereka tiru, terutama pada buku cerita anak.

Ada beberapa penelitian kebahasaan yang menggunakan kajian kesantunan di dalam sebuah novel. Salah satu dari penelitian tersebut ialah tesis yang berjudul Realisasi Kesantunan Berbahasa dalam Novel Ronggeng Dukuh Paruk Karya Ahmad Tohari yang ditulis oleh Nurhayati pada tahun 2010. Buku cerita anak yang diteliti dalam penelitian ini adalah buku cerita anak yang berjudul Abangku Sayang yang ditulis oleh Marion Rayhan Az Zahra yang masih berumur 11 tahun. Buku cerita ini begitu populer di kalangan anak-anak, selain ceritanya yang menarik, dan juga serial dari cerita KKPK (Kecil-Kecil Punya Karya) yang diterbitkan oleh Mizan ini pesan yang disampaikan di dalamnya pun begitu sarat dengan nilai-nilai pendidikan sehingga dapat menjadi sarana pendidikan, salah satunya pendidikan dalam kesantunan berbahasa. Oleh sebab itu, peneliti memilih buku cerita ini untuk diteliti tindak tutur serta kesantunan berbahasa di dalamnya agar anak-anak yang membaca buku cerita ini bisa mendapatkan pesan-pesan yang baik melalui buku cerita anak ini.

Kesantunan dalam berbahasa yang terdapat dalam buku cerita anak ini merupakan salah satu pesan yang secara tidak langsung disampaikan di dalam sebuah buku cerita anak. Teori kesantunan yang digunakan dalam penelitian ini ialah teori kesantunan dari Leech. Dalam model kesantunan Leech (dalam Rahardi 2008: 66-67), setiap maksim interpersonal itu dapat dimanfaatkan untuk menentukan peringkat kesantunan sebuah tuturan. Dengan menggunakan tindak tutur, kita dapat melihat skala kesantunan teori Leech.

\section{METODE}

Jenis penelitian ini termasuk jenis analisis wacana. Stubs (dalam Arifin dan Rani, 2000:8) menyatakan bahwa analisis wacana adalah suatu kajian yang meneliti atau menganalisis bahasa yang digunakan secara alamiah, baik dalam bentuk tulis maupun lisan. Analisis wacana ialah telaah mengenai aneka fungsi (pragmatik) bahasa (Badara, 2012: 18). Stubs juga menjelaskan bahwa analisis wacana menekankan kajian penggunaan dalam konteks sosial, khususnya dalam interaksi antarpenutur.
Penelitian ini merupakan penelitian kualitatif dengan menggunakan pendekatan pragmatik dengan metode deskriptif. Jenis penelitian ini termasuk jenis analisis wacana. Sumber data penelitian ini adalah buku cerita anak Abangku Sayang karya Marion Rayhan Az Zahra yang diterbitkan PT Mizan Pustaka dengan ketebalan buku 128 halaman. Buku cerita anak ini merupakan buku cetakan pertama pada tahun 2014 . Penelitian ini dilakukan dalam beberapa tahap, yaitu pengkajian sumber data, pengidentifikasian data, pengklasifikasian data, pendeskripsian data, dan penyimpulan data.

Data penelitian ini dikumpulkan dengan buku cerita anak Abangku Sayang untuk menemukan tindak tutur dan kesantunan yang terdapat di dalamnya. Teknik yang digunakan dalam penelitian ini ialah studi pustaka dan teknik catat. Peneliti membaca dan memahami cerita dan bentuk komunikasi dalam buku cerita Abangku Sayang. Peneliti mencatat setiap kutipan atau kalimat yang berisikan tuturan yang mengandung kesantunan, kemudian mengidentifikasi dan mengklasifikasikannya.

Penelitian bahasa dengan pendekatan pragmatik akan selalu menghubungkan bahasa dengan konteks pemakaiannya. Untuk itu, analisis data dalam penelitian ini dilakukan dengan metode analisis kontekstual. Rahardi (2008:16) mendefinisikan metode analisis kontekstual sebagai cara-cara analisis yang diterapkan pada data dengan mendasarkan, memperhitungkan, dan mengaitkan identitas kontekskonteks yang ada.

Analisis data dalam penelitian ini memiliki beberapa tahap sebagai berikut. (1) Melakukan pembacaan secara cermat dan berulangulang terhadap. (2) Pencatatan tuturan yang mengandung kesantunan berbahasa (3) Pengategorian data berdasarkan skala kesantunan. (4) Pendeskripsian data berdasarkan hasil skala kesantunan Leech. (5) Menyimpulkan data berdasarkan hasil penelitian.

\section{HASIL DAN PEMB AHASAN}

\section{Tindak Tutur}

\section{Tindak Tutur Representatif/Asertif}

Tindak tutur representatif ditemukan dalam data berikut ini. 
"Lah, ngapain numpang nonton TV di kamar orang lain? Di kamar kaka juga ada, kan?" tanyaku.(1)

"Ya, pengen aja nonton TV di sini. Toh, kamarmu juga bagus, catnya berwarna coklat, enggak seperti anak perempuan biasanya," katanya santai. (2)

Dari kutipan percakapan di atas, tuturan (2) merupakan respon atas pertanyaan yang diajukan pada tuturan (1). Tuturan (2) tersebut berupa paparan tentang keinginan penutur untuk menonton TV di kamar adiknya. Meskipun pada tuturan (2) penutur menjawab pertanyaan pada tuturan (1) dengan jawaban "ya, pengen aja nonton TV di sini...", tetapi pada kalimat berikutnya penutur mencoba menguraikan alasan yang lebih mengapa dia tertarik untuk menonton di kamar tersebut. Hal tersebut diindikasikan dengan kalimat "Toh, kamarmu juga bagus, catnya berwarna coklat, enggak seperti anak perempuan biasanya". Seandainya warna kamar mitra tutur (adiknya) tidak seperti warna yang disebutkan penutur, tetapi warna seperti anak perempuan kebanyakan, misalnya pink, hal tersebut memungkinkan penutur enggan untuk menonton di kamar tersebut. Dengan demikian, penutur telah berusaha memaparkan alasannya untuk menonton TV di kamar tersebut.

\section{Tindak Tutur Komisif}

Tindak tutur komisif ditemukan dalam data berikut ini.

Tuturan: Ada di aula, nanti aku antar kamu ke sana, ya.

Konteks: Dituturkan ketika Rara dan temannya Anita di dalam kelas ketika jam is tirahat

Fungsi Tindak Tutur: Tukar menukar informasi faktual (melaporkan)

Maksim: Kedermawanan

Dari data tersebut terdapat tindak tutur komisif jenis mengusulkan. Hal tersebut diindikasikan dengan penggunaan kata penunjukan waktu, yaitu nanti. Selain itu, tuturan tersebut dikategorikan ke dalam jenis mengusulkan karena tuturan tersebut terlahir tanpa adanya indikasi paksaan, ajakan, maupun intimidasi dari mitra tutur. Tuturan tersebut terlahir atas inisiatif penutur sendiri. Meski dalam tuturan yang terdapat pada data ini tidak terdapat kata modalitas yang menunjuk pada suatu pengusulan, tetapi tuturan tersebut dapat dikategorikan ke dalam jenis mengusulkan. Kalimat "Nanti aku antar kamu ke sana, ya," telah mengikat penutur untuk menemani mitra tutur ke suatu tempat nanti, waktu yang akan datang setelah tuturan itu dibuat baik dalam kurun waktu dekat ataupun lama. Dengan kata lain, usulan yang diutarakan penutur telah mengikatnya untuk melakukan sesuatu di waktu yang akan datang terhadap mitra tutur.

\section{Tindak Tutur Direktif}

Tindak tutur direktif larangan ditemukan dalam data berikut ini.

Tuturan: Lho, kok kamu seperti itu? Tidak sopan!

Konteks: Di meja makan sewaktu semua keluarga berkumpul untuk sarapan.

Fungsi Tindak Tutur: Direktif (larangan)

Maksim: Kearifan

Tuturan yang terdapat pada data (3) tersebut menggunakan tindak tutur direktif jenis larangan. Meskipun dalam tuturan tersebut tidak terdapat kata larangan seperti jangan, tetapi kata negasi tidak dapat menjadi indikasi kalimat tersebut merupakan kalimat larangan. Kalimat "Tidak sopan!" menunjukkan bahwa penutur melarang mitra tutur untuk mengulangi perbuatannya yang menjawab salam dengan ketus.

\section{Tindak Tutur Ekspresif}

Tindak tutur direktif larangan ditemukan dalam data berikut ini.

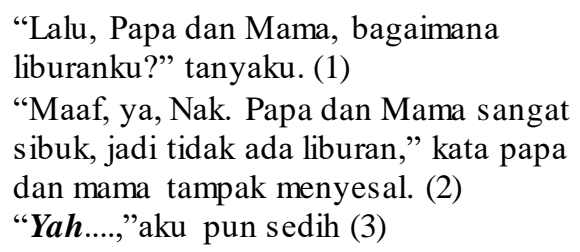

Dari kutipan percakapan tersebut dapat kita ketahui bahwa penutur mengungkapkan kekecewaannya dengan berkata yah. Kekecewaan tersebut bersumber dari liburan yang diharapkan oleh penutur tidak diwujudkan oleh ayah dan mama karena mereka sangat sibuk. Hal tersebut tentu menimbulkan kekecewaan dalam hati penutur. Kata yah telah mewakili penutur 
untuk mengungkapkan perasaan kekecewaannya terhadap jawaban yang diberikan pada tuturan (2).

\section{Tindak Tutur Deklaratif}

Seorang MC (Master Ceremony) dalam suatu perlombaan memiliki power dalam mengatur sebuah acara perlombaan. Dengan tuturan "let's start it now!" seorang MC memulai sebuah perlombaan. Tuturan tersebut merupakan tindak tutur deklaratif jenis menetapkan. Di sini, posisi penutur sebagai MC (Master Ceremony) yang memiliki peranan penting dalam memimpin/memandu jalannya perlombaan. "Let's start it now?" merupakan pertanda bahwa perlombaan telah dimulai. Kalimat tersebut pulalah yang mengubah keadaan dalam perlombaan tersebut, yang pada mulanya peserta tidak diperkenankan melakukan apapun menjadi diperbolehkan untuk mulai menggambar.

\section{Kesantunan}

\section{Maksim Kearifan}

Maksim kearifan ditemukan dalam data berikut ini.

"Jadi, begini. Aku, kan lagi tidur. Tiba-tiba Kak Mirza menyiramiku dengan air. Alhasil, aku basah kuyup. Seprai, bantal, serta selimutku juga basah. Untunglah kasurku tidak basah karena seprainya berbahan tebal. Sekarang Mbak Minah sedang menggantinya," jelasku. (1) "Mirza!" panggil mama. (2)

“Apa?" tanya Kak Mirza santai. (3)

"Kok kamu malah santai? Seharusnya kamu minta maaf. Tidak sepantasnya kamu membangunkan adikmu seperti itu. Kamu tidak kasihan kepada adikmu?" tanya mama. (4)

“Aku, kan, Cuma bercanda," jawabnya. (5)

"Tapi kamu harus minta maaf sekarang. Cepat!” tampaknya, mama juga kesal, sedangkan papa hanya diam membaca koran. (6)

"Iya, deh. Ra, Kakak minta maaf," Kak Mirza menjulurkan tangannya kepadaku. (7) Aku menjabat tangannya. "Iya. Aku maafkan," kataku. (8)
Dari kutipan percakapan di atas dapat kita ketahui bahwa mitra tutur (Kak Mirza) dalam pembahasan ini telah melakukan kesalahan, yaitu membangunkan adiknya dengan menyiramnya dengan air sehingga basah kuyup. Kesalahan tersebut tentu merugikan mitra tutur, apalagi mama pada tuturan (6) telah mengancam muka mitra tutur. Hal tersebut semakin meningkatkan kerugian pada posisi mitra tutur. Hal yang harus dilakukan oleh mitra tutur ialah dengan meminta maaf sebagaimana yang tercermin dalam tuturan (7). Penutur mempertimbangkan skala status hubungan sosial. Mitra tutur merupakan kakak penutur. Hal ini tentu menjadi pertimbangan sendiri bagi penutur untuk mengurangi kerugian yang dialami oleh mitra tutur (kakaknya). Dengan demikian, dengan memberikan jawaban sebagimana yang dituturkannya pada tuturan (8), penutur telah berusaha untuk mengurangi kerugian mitra tutur. Hal tersebut termasuk dalam maksim kearifan yang pertama, yaitu membuat kerugian orang lain sekecil mungkin.

\section{Maksim Kedermawanan}

Tuturan "Kalian mau menginap di sini?" mengindikasikan bahwa penutur telah berlaku santun dalam tuturannya. Kesantunan tersebut terlihat dari bentuk tuturannya yang tidak langsung. Di sini, penutur mempertimbangkan skala ketidaklangsungan. Dalam tuturannya yang berbentuk direktif ini, penutur telah meminimalisasi keuntungan dirinya dengan menggunakan kalimat interogatif dalam perintahnya. Dengan demikian, penutur telah berlaku santun dengan memenuhi maksim kedermawanan.

Skala pilihan juga dipertimbangkan dalam kesantunan ini.Penutur tidak memaksakan mitra tutur untuk menginap di rumahnya.Penutur memberikan keleluasaan kepada mitra tutur untuk memilih menginap atau tidak.Skala pilihan ini ditunjang dengan penggunaan kalimat interogatif pada tuturan penutur. Hal tersebut akan berbeda jauh jika penutur menggunakan kalimat "menginaplah di sini" atau "kalian harus menginap malam ini".

\section{Maksim Pujian}

Maksim pujian ditemukan dalam data berikut ini. 
"Lah, ngapain numpang nonton TV di kamar orang lain? Di kamar Kakak juga ada, kan?” tanyaku. (1)

"Ya pengin aja nonton TV di sini. Toh, kamarmu juga bagus, catnya berwarna cokelat, enggak seperti anak perempuan biasanya." katanya santai. (2)

Dari kutipan percakapan di atas dapat kita ketahui bahwa penutur tidak secara langsung menjawab pertanyaan yang diajukan pada tuturan (1). Jika kita amati isi tuturan (2), di dalamnya tersirat bahwa penutur tuturan (2) merasa nyaman di kamar tersebut karena tidak seperti kamar anak perempuan kebanyakan yang biasanya bernuansa feminim. Isi tuturan ini tidak secara langsung disampaikan penutur bahwa penutur merasa nyaman sehingga ia ingin menonton TV di kamar tersebut. Penutur mempertimbangkan skala ketidaklangsungan dengan mengatakan bahwa dirinya hanya ingin saja nonton di tempat itu. Dengan mengatakan "Ya pengin aja nonton TV di sini", penutur dapat menciptakan sebuah kecurigaan dalam pemahaman mitra tutur. Pernyataan seperti itu dapat disalahartikan dengan ada maksud tertentu di dalamnya.

Kecurigaan dalam pemahaman yang dapat disalahartikan ini telah diminimalisasi oleh penutur dengan menggunakan kesantunan maksim pujian.Dengan memuji kamar mitra tutur, penutur telah memperjelas maksud penutur mengapa dia ingin menonton di kamar itu. Dengan demikian, mitra tutur dapat mengetahui alasan yang jelas dari penutur tanpa secara langsung penutur mengatakannya.

\section{Maksim Kerendahan Hati}

Maksim kerendahatian ditemukan dalam data berikut ini.

Tuturan: Mmm... sebenarnya aku mau minta maaf ke Kakak. Aku memang terlalu sensitif juga.

Konteks: Rara ke kamar Kak Mirza dan meminta maaf.

Fungsi Tindak Tutur: Mengungkapkan sikap moral (meminta maaf)

Data tersebut menunjukkan bahwa dalam tuturan penutur terdapat kesantunan berbahasa dengan maksim kerendahan hati. Hal ini terjadi karena penutur telah mengecam dirinya sebanyak mungkin. Permohonan maaf yang meru- pakan tindakan mengecam diri sendiri tersebut dimaksimalkan oleh penutur dengan mengatakan "Aku memang terlalu sensitif juga". Hal ini menunjukkan bahwa penutur benar-benar telah mengecam dirinya semaksimal mungkin. Penutur menyalahkan dirinya atas kejadian yang telah lalu dan membuat pernyataan bahwa memang dirinyalah yang bersalah karena terlalu sensitif. Dengan demikian, penutur telah mengecam dirinya sendiri semaksimal mungkin.Hal ini memenuhi maksim kerendahan hati.

\section{Maksim Kesepakatan}

Maksim kesepakatan ditemukan dalam data berikut ini.

\footnotetext{
“Nah, sekarang kamu sarapan,(1)” ajak mama.

"Iya, Ma" aku menganggukkan kepala, lalu memulai sarapan dengan pancake yang diberi saus maple. (2)
}

Dari kutipan percakapan di atas dapat kita ketahui bahwa penutur tuturan (1) telah mengajak penutur (Rara) untuk sarapan. Dengan memaksimalkan kesepakatan dirinya dengan orang lain (penutur tuturan (1), penutur (Rara) mengiyakan ajakan tersebut. Skala yang dipertimbangkan dalam kesantunan ini ialah skala keotorisasian.Mengingat yang mengajak ialah mama, orang tua mitra tutur. Dengan demikian, penutur mencoba bertindak santun dalam tuturannya dengan menuruti ajakan tersebut. Hal tersebut mengindikasikan bahwatelah terjadi kesantunan di dalam tuturannya, yaitu dengan memaksimalkan kesepakatan antara diri sendiri dengan orang lain.

\section{Maksim Simpati}

Maksim kesepakatan ditunjukkan pada data berikut ini.

Tuturan: Oh, iya, ngomong-ngomong, Kakak emangnya mau diet? Masa Cuma pesan salad buah dan yoghurt?

Konteks: Dituturkan ketika Rara dan keluarga pergi liburan ke Puncak Fungsi Tindak Tutur: Tukar menukar informasi faktual (bertanya)

Data tersebut menunjukkan bahwa penutur telah berusaha untuk simpati kepada mitra 
tutur. Simpati tersebut dengan menanyakan kepada mitra tutur tentang pola makannya. Dengan tuturan ini, penutur telah berusaha memaksimalkan rasa simpatinya kepada orang lain. Hal tersebut memenuhi kesantunan maksim simpati. Kesantunan yang terkandung dalam data di atas mempertimbangkan skala status sosial.Jarak status sosial antara penutur dengan mitra tutur berbeda. Status penutur sebagai adik mitra tutur membuat penutur harus bertutur santun.

\section{PENUTUP}

Berdasarkan hasil penelitian disimpulkan bahwa terdapat lima jenis tindak tutur yang digunakan dalam percakapan dalam buku cerita anak Abangku Sayang, yaitu tindak tutur representatif berupa menyatakan, paparan, pengeluhan, laporan, dan menunjukkan. Tindak tutur komisif berupa berjanji dan mengusulkan. Tin-

\section{DAFTAR PUSTAKA}

Alisjahbana, S. Takdir. 1977. Perjuangan Tanggung jawab dalam Kesusastraan. Jakarta: Dunia Pustaka Jaya.

Arifin, Bustanul dan Abdul Rani. 2000. Prinsipprinsip Analisis Wacana. Jakarta: Depertemen Pendidikan Nasional. dak tutur direktif berupa menyuruh, melarang/ larangan, perintah, pertanyaan, menasihati, mengajak, mengingatkan, mempersilakan, dan menyarankan. Tindak tutur ekspresif berupa pujian, meminta maaf, menyapa, berterima kasih, mengungkapkan rasa senang, mengungkapkan kekecewaan, dan mengkritik. Kemudian yang terakhir adalah Tindak tutur deklaratif berupa menetapkan, mengizinkan, dan menghukum.

Dalam buku cerita anak Abangku Sayang karya Marion ini juga ditemukan kesantunan dalam berbahasa yang memenuhi keenam maksim kesantunan yang dikembangkan Leech, yaitu maksim kearifan, maksim kedermawanan, maksim pujian, maksim kerendahan hati, maksim kesepakatan, dan maksim simpati. Penerapan kesantunan yang paling dominan ialah maksim yang berkaitan dengan untung-rugi, yaitu maksim kearifan.

Badara, Aris. 2012. Analisis wacana: Teori, Metode, dan Penerapannya pada Wacana Media. Jakarta: Kencana.

Rahardi, R. Kunjana. 2008. Pragmatik: Kesantunan Imperatif Bahasa Indonesia. Yogyakarta: PT Gelora Aksara Pratama. 